\title{
Exploring Factors Influencing Customers Decision Making towards Online Grocery Retail Services in Kolkata
}

\author{
Dr. Namrata Maheshwari
}

\author{
Assistant Professor, J. D. Birla Institute, Kolkata, India. namratamaheshwari23@gmail.com
}

\begin{abstract}
Online grocery retail services are a new trend in Indian urban cities. The two large players namely Grofers and Big Basket are attracting customers. The study is an attempt to understand the changing scenario in grocery retail sector. The prime objective of the study is to explore the factors that are attracting customers to choose e retail for Groceries. The data was collected through questionnaire from 100 respondents. Factor analysis (Principle Component Analysis method) was used to explore the influencing factors. These results have shown that mainly customer service, convenience, loyalty rewards, product availability and payment options are attracting the customers to choose Grophers and Big Basket. These companies have a huge untapped markets and will easily convert the habits of customers in Urban areas.
\end{abstract}

Keywords: Grofers, Big basket, Factors, Customers, Online Grocery.

\section{INTRODUCTION}

Online grocery retailing in India is a largely unorganized space. Also it poses a big challenge in terms of stiff entry barriers, existing big players in offline sectors. With the current mushrooming of online grocery portals through digital mode, there are hidden opportunities in this sector. There are numerous players who have entered and trying to influence customers. Indian online grocery shoppers have found buying grocery online convenient, comfortable and hassle free. Online grocery stores are gaining popularity in India due to sheer convenience, ease of shopping and a fastgrowing market. Some popular online players in the Indian grocery market are BigBasket, Grofers, Nature's Basket and Zopnow. These firms have been active for about three years each and have seized a hefty market share in their respective cities of operations. The ascend in the public's requirements for convenience shopping coupled with the dissemination of in terms of among the population hassled to the growth of this industry at a rapid pace. The market also flourishes, as it has been able to tender sharp discounts on the prices of the grocery items offered and attract customers away from the traditional neighborhood grocery stores to online grocery shopping. This also reveals that customers from the hassle of carrying their bags, refrains them to face parking and traffic problems, as well as the long queues in their neighborhood local markets or supermarkets

\section{LiteratURE REVIEW}

Banerjee. A and T. Banerjee (2016) analyzed that happiness with the experience of using the online grocery web site is positively correlated to delivery of groceries. They concluded that consumers are satisfy from experience of online groceries and their products too. Baheti .V and L. Kaushal (2015) evaluated the impact of varied attributes on the consumers' attitude towards online grocery shopping. Perceived Cost, Convenience, Risk and Enjoyable were the four attributes. The findings for perceived cost revealed that there was no significant difference among the various demographic traits of the consumers. However, significant difference was found in the customers who are aware and not aware of online grocery shopping. Sathiyaraj S. (2015) summarised that if online retailers know the factors affecting Indian consumers' buying behavior, and the associations between these factors and type of online buyers, then they can further develop their marketing strategies to convert potential customers into active ones. The outcome of the research paper also revealed that the demographic variables, such as gender, age group don't have influence of the factors of customer satisfaction. Raut. $\mathrm{V}$ and S. Walvekar (2014) suggested that there are some factors Security, Reliability \& Service, and References, that has to be considered if the marketer want to motivate their customers for online purchases. Kumar, \& Verma (2014) concluded that the level of education, income, needs of the people and the platform which was required to catapult eretailing is in consonance with urban infrastructure and its demographic aspirations. Mattila (2013) conducted a study on Online Shopping Adoption Factors and identified six factors affecting the adoption of electronic grocery shopping were examined. This study also showed that consumers valued several factors in electronic grocery shopping such as wide range of and familiar products and brands, freedom from time and place, time saving, and as stated, convenience. Mishra \& Mathew (2013) showed that Indian online users had high level of perceived risks, highest fear being related to the delivery of products purchased online. Information quality, product range and after online sales service are most preferred website attributes which influence Indian online users.Coupey et al. 
(2009) perceived numerous inhibiting factors to online grocery shopping and few motivating factors. Interestingly, contrary to other ecommerce sectors, the grocery sector suffers from a very bad price image while consumers have a high price sensibility for food purchase. Huang and Oppewal (2006) showed that all four situational factors affect consumers' shopping channel preference, though of influence, delivery charges are not the most important factor.

\section{Aims and Objectives}

- To identify the factors affecting consumer's decision towards shifting from Offline Grocery retail stores to Online Grocery Stores (considering only Grofers and Bigbasket) in Kolkata.

- To identify whether the consumer's demographics are affecting their consumption pattern with respect to Grofers and BigBasket inKolkata.

\section{RESEARCH METHODOLOGY}

The study is designed to explore the factors affecting consumer's decision making towards Grofers and Big basket in Kolkata. The study also tried to find out whether online grocery shopping can be affected by the demographics of consumers. In the research methodology, quantitative and qualitative, are used in research and in this study only Qualitative method is used. Quantitative research, which emphasizes quantification in the data collection and analysis, is based on the ideals of positivism (Cavana et al. 2001; Bryman and Bell 2011). The sample size of the study is 100 respondents. In order to achieve the research objectives, data was collected by questionnaire method through online and offline mode. The questionnaire was prepared with using close-ended questions. There were different variables to identify the factors and Likert scale was used to identify customers' opinions. SPSS and MS Excel were used to analyze the data. ANOVA Test and Factor analysis were used to evaluate the results. The reliability test showed the validity of the variables then the questionnaire was floated and data was collected through convenience sampling.

\section{Findings AND RESULTS}

The majority of the respondents were female $(67 \%)$,working professional(46\%), having age group of 25 35 years $(77 \%)$, were having monthly income of Rs.60000100000.There were around 38\% respondents who were using Grofers and 36\% were using only Big Basket and Table 2: KMO and Bartlett's Test
$28 \%$ were using both brands. Factor analysis was used to investigate the variables affecting consumer's decisionmaking in online retail shopping.

One-way ANOVA test was used to find out the impact of socio-economic variables on the consumption pattern towards Grofers and BigBasket. To identify the impact of socio-economic profiles (Gender, Age, Education Level, Occupation, Income and Marital Status) on the consumption pattern towards Grofers and BigBasket, following Hypothesis is tested:-

$\left(\mathrm{H}_{0}\right)$ : There is no significant association between the impact of socio-economic variables on the consumption pattern towards Grofers and BigBasket.

$\left(\mathrm{H}_{1}\right)$ : There is significant association between the impact of socio-economic variables on the consumer's consumption pattern towards Grofers and BigBasket.

Table 1: ANOVA results for the impact of socio-economic variables on the consumption pattern towards Grofers and BigBasket

\begin{tabular}{|c|c|c|c|c|c|c|}
\hline $\begin{array}{l}\text { Source of } \\
\text { Variation }\end{array}$ & נינה & $\begin{array}{l}\text { Degree } \\
\text { of } \\
\text { Freedom }\end{array}$ & Ino & $\begin{array}{l}F- \\
\text { statistics }\end{array}$ & $1-v u u u$ & $\begin{array}{l}\text { F critical } \\
\text { value }\end{array}$ \\
\hline Between & 617.4745 & 7 & 88.21064 & 80.95753 & $3.96 \mathrm{E}-89$ & 2.020783 \\
\hline Within Groups & 889.1068 & 816 & 1.089592 & & & \\
\hline Total & 1506.581 & 823 & & & & \\
\hline
\end{tabular}

The test results show that F-statistics value, 80.95753 is more than the F Critical value of 2.020783, indicating that the null hypothesis $\left(\mathrm{H}_{0}\right)$ is rejected and alternative hypothesis $\left(\mathrm{H}_{1}\right)$ is accepted at $5 \%$ level of significance. This indicates that there is an impact of socio-economic variables on the consumer's consumption pattern towards Grofers and BigBasket.

\section{FaCtor AnAlysis}

Factor analysis with principal component analysis of consumer's preference towards online grocery shopping and factors affecting online grocery shopping.After applying factor analysis, the present study used the 17 items for identifying the key factors and determinants influencing the consumers' preference towards online grocery shopping. These variables were measured on 5 point Likert scale, where 5 represented 'Very important' or 'Agree' and 1 represented 'Least important' or 'Totally disagree'.

\begin{tabular}{lll}
\hline KMO and Bartlett's Test & & \\
\hline Kaiser-Meyer-Olkin Measure of Sampling Adequacy. & & .887 \\
& Approx. Chi-Square & 1572.170 \\
Bartlett's TestofSphericity & Degree of Freedom & 190 \\
& Sig. & .000 \\
\hline
\end{tabular}


The above table reflects two tests that indicate the suitability of the data for structure detection. The KaiserMeyer-Olkin (KMO) Measure of Sampling Adequacy is a statistic which indicates the proportion of variance in the variables that might be caused by underlying factors. The value of KMO test is 0.887 which is greater than 0.6, thereby indicating that the data is highly suited for factor analysis and will yield useful results. The value of Bartlett's test is 0.000 which is less than 0.05 of the significance level, thereby indicating the factors analysis will yield useful results.

Table 3: Communalities

\begin{tabular}{|c|c|c|}
\hline Communalities & & \\
\hline Better Price & $\begin{array}{l}\text { Initial } \\
1.000\end{array}$ & $\begin{array}{l}\text { Extraction } \\
.460\end{array}$ \\
\hline Better Quality Products & 1.000 & .838 \\
\hline Home Delivery Facility & 1.000 & .707 \\
\hline Easy Returns Policy & 1.000 & .637 \\
\hline Product Availability & 1.000 & .656 \\
\hline Flexible Time Slots & 1.000 & .784 \\
\hline Referral benefits & 1.000 & .660 \\
\hline Cash back Offers & 1.000 & .560 \\
\hline Payment Discounts & 1.000 & .726 \\
\hline Easy cancellation & 1.000 & .887 \\
\hline Availability of In-house brands & 1.000 & .637 \\
\hline Wide Product Assortment & 1.000 & .957 \\
\hline Possibility of Comparison of Different Products & 1.000 & .601 \\
\hline Affordable Delivery Charges & 1.000 & .957 \\
\hline Cash Free Transactions & 1.000 & .908 \\
\hline Multiple Payment Methods & 1.000 & .798 \\
\hline Extraction Method: Principal Component Analysis. & (1) & \\
\hline
\end{tabular}

Source: Primary data, SPSS

Table 4: Total Variance Explained

(

\begin{tabular}{|c|c|c|c|c|c|c|}
\hline \multirow{2}{*}{ Component } & \multicolumn{3}{|c|}{ Tmitin1 Linan unlwar } & \multicolumn{3}{|c|}{$\begin{array}{l}\text { Extraction Sums of Squared } \\
\text { Loadings }\end{array}$} \\
\hline & Total & $\begin{array}{l}\text { \% of } \\
\text { Wariance }\end{array}$ & $\begin{array}{l}\text { Cumulative } \\
\%\end{array}$ & Total & $\begin{array}{l}\text { \% of } \\
\text { Wariance }\end{array}$ & $\begin{array}{l}\text { Cumulative } \\
\%\end{array}$ \\
\hline 1 & 2.404 & 14.139 & 14.139 & 2.404 & 14.139 & 14.139 \\
\hline 2 & 2.276 & 13.386 & 27.525 & 2.276 & 13.386 & 27.525 \\
\hline 3 & 1.694 & 9.965 & 37.490 & 1.694 & 9.965 & 37.490 \\
\hline 4 & 1.522 & 8.952 & 46.442 & 1.522 & 8.952 & 46.442 \\
\hline 5 & 1.270 & 7.471 & 53.914 & 1.270 & 7.471 & 53.914 \\
\hline 6 & 1.194 & 7.025 & 60.939 & 1.194 & 7.025 & 60.939 \\
\hline 7 & 1.098 & 6.456 & 67.395 & 1.098 & 6.456 & 67.395 \\
\hline 8 & 1.018 & 5.988 & 73.383 & 1.018 & 5.988 & 73.383 \\
\hline 9 & 0.899 & 5.286 & 78.669 & & & \\
\hline 10 & 0.749 & 4.407 & 83.076 & & & \\
\hline 11 & 0.744 & 4.375 & 87.451 & & & \\
\hline 12 & 0.638 & 3.753 & 91.204 & & & \\
\hline 13 & 0.577 & 3.396 & 94.600 & & & \\
\hline 14 & 0.491 & 2.890 & 97.491 & & & \\
\hline 15 & 0.344 & 2.024 & 99.515 & & & \\
\hline 16 & 0.082 & 0.485 & 100.000 & & & \\
\hline $17 x$ & $\begin{array}{l}-6.687 \mathrm{E}- \\
16\end{array}$ & $\begin{array}{l}-3.933 \mathrm{E}- \\
15\end{array}$ & 100.000 & & & \\
\hline \multicolumn{7}{|c|}{ Extraction Method: Principal Component Analysis } \\
\hline
\end{tabular}


Component 1 (Customer Service)- The analysis suggests that customer service plays a key role in determining their preference towards Online Grocery Shopping that includes Easy cancellation option available to them and Cash Free Transactions while ordering Groceries Online.

Component 2 (Convenience)-The analysis suggests that convenience like Availability of Full Product Description, Affordable Delivery Charges and Wide Product Assortment while using the Online Grocery Shopping Portals.

Component 3 (Loyalty Rewards)-The analysis suggests that Loyalty Rewards plays a key role in determining their preference towards Online Grocery Shopping. Loyalty Rewards like Referral Benefits Received after referring the application to your friends and Family.

Component 4 (Product and Price Mix)- The analysis suggests that Product and Price mix like Availability of Full Product Description and Multiple Payment Options while placing an Order.

Component 5 (Time Flexibility)-The analysis suggests that Time Flexibility plays a key role in determining their preference towards Online Grocery Shopping. Time Flexibility services like Flexible Time Slots available for the customers who shop grocery online.

Component 6 (Delivery Facility)-The analysis suggests that Delivery Facility plays a key role in determining their preference towards Online Grocery Shopping. Delivery Facility services like Home Delivery Facility available for the customers who shop grocery online.

Component 7 (Product Quality)- The analysis suggests that Product Quality plays a key role in determining their preference towards Online Grocery Shopping. Product Quality services like Better Quality Products available for the customers who shop grocery online.

\section{CONCLUSION}

The online grocery retail sector is still in the initial stages of growth and has just started to pick up some pace but it is confirmed that there is hidden opportunities lying in this sector. Due to technological advancements, this sector will see a boom in future. E-grocery retailers can develop brand equity, generate customer loyalty, repeat purchase and it will bring succession growth in this sector. The study showed that due to convenience, online grocery shopping is mainly accepted. By ordering online, one can quickly search for the products one needs and order them without having to go through those long aisles. The results of the hypothesis stated that there is a positive and significant association between the impact of socio- economic variables on the consumption pattern towards Grofers and Bigbasket. There is no doubt about it, that the market will remain challenging for the current generation of online grocery retailers but big brands will see the success easily after some period. These online grocery businesses will stick to adding more value, will also garner the advantage of being the early bird, since they already have captured the market while it continues to become mainstream with new technology. However, traditional and offline retailers are also bound to add value in their business for sustaining in this market. In india, the transition from offline to online retail business is dependent upon changing habits of consumers and their acceptance to new players. The thought of changing trends in retail is bring more development in Indian market.

\section{REFERENCES}

[1] Andrews ARL, Currim IS. Behavioural differences between consumers attracted to shopping online versus traditional supermarkets: Implications for enterprise design and marketing strategy. International Journal of Internet Marketing and Advertising. 2004; 1(1):38-61.

[2] Baheti V, Leena AK. E-analysis of consumers' attitudes towards online grocery shopping. A case study in Indian context www.theinternationaljournal.org > RJSSM. 2015; 05(7).

[3] Banerjee A, Banerjee T. Web Content Analysis of Online Grocery Shopping Web Sites in India Indian Institute of Management Ahmedabad; 2016.

[4] Bawa K, Ghosh A. A model of household grocery shopping behaviors. Marketing letters. 1999; 10(2):149-60.

[5] Belkud R. Developing a new Internet Grocery Retail Shop concept for the Indian Cosnumers. Laurea University of Applied Sciences. 2013. p.7-75.

[6] Corbett JJ. Is Online Grocery Shopping Increasing in Strength?. Journal of Food Distribution Research. 2001; 32 (01):37-40.

[7] Coupey PK, Huré E, Cliquet G, Petr C. (2009) Grocery shopping and the Internet: exploring French consumers' perceptions of the 'hypermarket'and 'cybermarket' formats. The International Review of Retail, Distribution and Consumer Research. 2009; 19(4):437455.

[8] Fong SH. A Study on Consumer's Attitude towards Online Shopping on Penang Famous Fruit Pickles. Faculty of Applies Social Sciences, Open University Malaysia; 2014.

[9] Huang Y, Oppewal H. Why consumers hesitate to shop online: An experimental choice analysis of grocery shopping and the role of delivery fees. International Journal of Retail \& Distribution Management. 2006; 34(4/5):334-353.

[10]Kramer M. The Unravelling of Apparel: Online Shopping behavior. Reinvention: An International Journal of undergradate Research. 2015;8(2). 